\title{
TOURNIQUET HYPERPNEA AND ITS MODIFICATION BY AGENTS WHICH ALTER CEREBRAL BLOOD FLOW*
}

\author{
By JOSEPH C. ROSS, JOHN B. HICKAM AND REGINA FRAYSER
}

\author{
(From the Department of Medicine and the Heart Research Center, Indiana University Medical \\ Center, Indianapolis, Ind., and from the Department of Medicine, Duke University \\ Medical School, Durham, N. C.)
}

(Submitted for publication July 31, 1961 ; accepted October 12, 1961)

When $\mathrm{CO}_{2}$ is added to the inspired gas of a normal resting subject, the $\mathrm{P}_{\mathrm{CO}_{2}}$ of arterial blood rises quickly, but the ventilation rate increases gradually. The lag of ventilation behind change in arterial $\mathrm{P}_{\mathrm{CO}_{2}}$ has been ascribed to the time required for the tissues of the respiratory center to come into balance with the altered $\mathrm{P}_{\mathrm{CO}_{2}}$ of the perfusing blood (1-3). The response of ventilation to change in arterial $\mathrm{P}_{\mathrm{O}_{2}}$ is more prompt, presumably because the peripheral chemoreceptors are more richly perfused $(2,4-7)$. These relationships have been well established, but there is little information about factors which can affect the rate at which ventilation responds to a bloodborne stimulus.

It is possible to produce an abrupt increase in arterial $\mathrm{P}_{\mathrm{Co}_{2}}$, as well as other arterial blood changes, by releasing tourniquets which have occluded blood flow through the legs for several minutes (8-11). A few seconds after the rise in arterial $\mathrm{P}_{\mathrm{CO}_{2}}$ begins, there is an abrupt increase in ventilation rate (Figure 1). It is found that the time of onset and the magnitude of this ventilation increase can be markedly altered by a variety of procedures which also have the common property of changing the rate of cerebral blood flow. It is, however, difficult to explain all of the observations satisfactorily in terms of our present understanding of the control of ventilation. It is the purpose of this report to present data on the production and modification of tourniquet hyperpnea with particular reference to apparent variations in the stimulus-response time of ventilation, and to speculate on the meaning of these data.

* This work was supported by Research Grant H-4080 from the National Heart Institute, National Institutes of Health, U. S. Public Health Service. This work was presented in part at the Cardiovascular Section of the Joint Sessions of the American Society for Clinical Investigation and the American Federation for Clinical Research, Atlantic City, N. J., May, 1959.

\section{METHODS}

The subjects were untrained normal male medical students with an age range of 21 to 31 years. They were not fasting and came to the experiment directly from their work.

In outline, the technique consisted of occluding circulation to the legs for 15 minutes by applying arterial tourniquets to the thighs and then releasing the tourniquets suddenly while the subject was breathing into a recording spirometer. Multiple arterial blood samples were withdrawn from an indwelling brachial artery needle before and after tourniquet release for analysis of the $\mathrm{pH}, \mathrm{CO}_{2}$, and $\mathrm{O}_{2}$ changes produced by this procedure.

In detail, the experimental procedure was as follows. The subject was placed in the supine position and a Cournand needle was inserted into a brachial artery. The needle was attached by plastic tubing to a manifold with a series of three-way stopcocks to which syringes were attached for rapid withdrawal of small blood samples. Wrap-around blood pressure cuffs, 8 inches in width, were placed on the upper thighs. The cuffs were inflated rapidly to a pressure above the arterial systolic pressure by releasing a clamp on the tubing between the cuffs and a 15-L carboy into which air had previously been compressed to over $300 \mathrm{~mm} \mathrm{Hg}$. The pressure in the cuffs was maintained at 180 to $200 \mathrm{~mm} \mathrm{Hg}$ (well over systolic pressure in all subjects) for the entire 15-minute period that the tourniquets were applied. During this period, subjects avoided any muscular activity below the tourniquets. Almost all subjects complained of some aching or cramping sensations in the legs, particularly underneath the tourniquets, for the first 3 to 5 minutes after cuff inflation. During the remainder of the 15-minute period, however, all subjects were relaxed and had little or no discomfort from the tourniquets. During the last 5 minutes of tourniquet application and the period after tourniquet release, subjects breathed from a 150-L Douglas bag through a Douglas valve into a 120 - $\mathrm{L}$ recording spirometer so that the ventilation rate could be continuously recorded. It is reported as ventilation at ATPS. Ventilation was recorded after tourniquet release until the rate had returned to the prerelease level. When the cuffs had been inflated for 15 minutes, they were released suddenly by opening an escape valve. At the time of tourniquet release, subjects experienced a brief sensation of tingling which generally subsided well 
before any ventilatory response occurred. Arterial blood samples were taken immediately prior to tourniquet release and at regular intervals for 1.5 to 2 minutes after tourniquet release. Each sample was withdrawn rapidly over a few seconds' time. Each sampling time reported is the midpoint of the sampling period. Blood was taken into oiled, heparinized syringes. For $\mathrm{pH}$ determinations, sodium fluoride was added as a preservative. The syr-

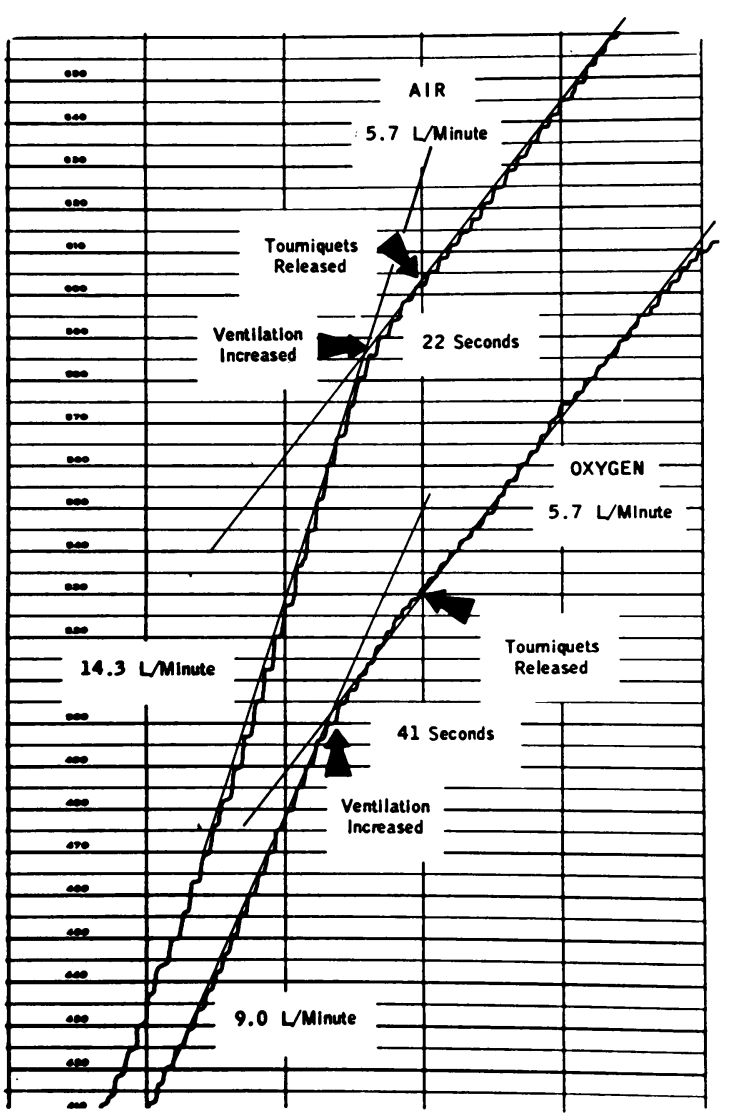

Fig. 1. SPIROMETER RECORD DURING TOURNIQUeT HYPERPNEA IN A NORMAL SUBJECT BREATHING AIR AND oXYGEN. The figure is a reproduction of an actual Tissot spirometer recording. The direction of drum rotation is such that time is increasing from right to left. The distance between vertical lines represents 1 minute. The arrows on the right indicate the moment of release of thigh cuffs which had been inflated above arterial pressure for 15 minutes. The arrows on the left indicate the onset of hyperpnea. The time intervals between tourniquet release and the onset of hyperpnea are printed beneath each tracing. The ventilation rates before and after tourniquet release, as measured by the straight lines drawn along the tracings, are shown in appropriate positions. For measurement purposes the intersection of these straight lines is considered to mark the onset of hyperpnea. With oxygen, the onset of hyperpnea is delayed and the ventilation increases less than when the subject is breathing air. inges were capped and stored in ice water and analyses were completed within 2 to 5 hours.

This entire procedure was carried out at least twice in every subject studied, once with air and once with tank oxygen (99.5 per cent) as the gas inspired from the Douglas bag during the last 5 minutes of tourniquet application and the period following tourniquet release. The order in which the studies were done was randomized from subject to subject, and the subjects did not know which gas was being breathed. In some subjects, this entire procedure was carried out under other special conditions described below.

In 5 subjects, the procedure was repeated with both air and oxygen breathing during sodium bicarbonate infusion. The subjects were given 400 to $500 \mathrm{ml}$ of 3.0 per cent $\mathrm{NaHCO}_{3}$ intravenously over a 30-minute period before tourniquet release. Three additional subjects were studied during $\mathrm{NaHCO}_{3}$ infusion with 3.0 per cent $\mathrm{CO}_{2}, 21.0$ per cent $\mathrm{O}_{2}, 76.0$ per cent $\mathrm{N}_{2}$, and 3.0 per cent $\mathrm{CO}_{2}, 97$ per cent $\mathrm{O}_{2}$ as the inspired gases.

Three subjects were studied during ammonium chloride infusion. These subjects were given approximately $200 \mathrm{ml}$ of 0.8 per cent $\mathrm{NH}_{4} \mathrm{Cl}$ intravenously over a 30-minute period before tourniquet release on air and an additional $150 \mathrm{ml}$ in the next 30 minutes before tourniquet release while they breathed oxygen.

In another 5 subjects, the procedures were carried out during aminophylline infusion. The subjects were given $300 \mathrm{mg}$ of aminophylline by infusion into an arm vein during the 30 minutes before tourniquet release on air and an additional $300 \mathrm{mg}$ during the following $30 \mathrm{~min}$ utes before tourniquet release while they breathed oxygen.

In 7 subjects tourniquets were not used, but ventilation was recorded continuously during the first 6 minutes of breathing two different gas mixtures containing approximately 4.5 per cent $\mathrm{CO}_{2}, 21.0$ per cent $\mathrm{O}_{2}$ and 74.5 per cent $\mathrm{N}_{2}$, and approximately 4.5 per cent $\mathrm{CO}_{2}, 95.0$ per cent $\mathrm{O}_{2}$ and 0.5 per cent $\mathrm{N}_{2}$, respectively. Each trial was preceded by a control period of at least 5 minutes during which the subject breathed air if the 21 per cent $\mathrm{O}_{2}$ mixture were to follow, or tank oxygen if the 95 per cent $\mathrm{O}_{2}$ mixture were to follow. $\mathrm{A}$ rest period of at least 15 minutes was allowed between trials. The order of presenting the two mixtures was varied. Switching from control to the $\mathrm{CO}_{2}$-containing mixture without the subjects' knowledge required an arrangement with extra lead-in tubing, so that an average of about 8 seconds was needed for the gas actually to reach the subject. Arterial samples were taken as above, without disturbing the subject, during the control period and usually at 1 minute and 6 minutes after switching to $\mathrm{CO}_{2}$.

The arterial blood oxygen capacity was determined by the method of Drabkin and Austin (12). Oxygen content and per cent oxygen saturation were determined by the spectrophotometric method of Hickam and Frayser (13). The $\mathrm{pH}$ of whole blood was measured with a Cambridge model $\mathrm{R} \mathrm{pH}$ meter equipped with an enclosed glass electrode. Measurements were made at room temperature, usually $25^{\circ}$ to $26^{\circ} \mathrm{C}$, and the result was cor- 
rected to $37^{\circ} \mathrm{C}$ by Rosenthal's factor (14). The carbon dioxide content of whole blood was determined by the method of Van Slyke and Neill (15), and duplicate analyses were required to check within 0.1 vol per cent. The plasma $\mathrm{CO}_{2}$ content was estimated from the blood $\mathrm{CO}_{2}$ content and from the $\mathrm{pH}$, hemoglobin concentration, and per cent oxygen saturation, by the line chart of Van Slyke and Sendroy (16). The arterial plasma $\mathrm{CO}_{2}$ tension was calculated from the $\mathrm{pH}$ and plasma content of $\mathrm{CO}_{2}$ at $37^{\circ} \mathrm{C}$ by the Henderson-Hasselbalch equation, using a $\mathrm{pK}$ of 6.11 (17). In this laboratory, $\mathrm{P}_{\mathrm{CO}_{2}}$ values by this method are reproducible to within $\pm 1.0 \mathrm{~mm} \mathrm{Hg}$.

\section{RESULTS}

The effects of breathing air and oxygen on the ventilatory response to tourniquet release were compared in a total of 35 subjects as to magnitude of ventilation increase and the interval between tourniquet release and onset of hyperpnea. Figure 1 is a reproduction of an actual spirometer tracing and shows the typical responses with air and oxygen breathing. Hyperpnea began abruptly in air-breathing subjects at about 25 seconds after tourniquet release and reached its full magnitude generally within 2 breaths. Ventilation maintained a nearly steady level for a minute or two, and then gradually declined to reach the resting level in about 3 minutes. Oxygen caused a marked reduction in the increment of ventilation
TABLE I

Effect of breathing air and oxygen on the magnitude and timing of hyperpnea after release of artery-occluding thigh tourniquets in 7 subjects

\begin{tabular}{cccc}
\hline Gas & Increase in & $\begin{array}{c}\text { Interval } \\
\text { between } \\
\text { ventilation } \\
\text { after } \\
\text { tourniquet } \\
\text { release and } \\
\text { release }\end{array}$ & $\begin{array}{c}\text { Contilation } \\
\text { increase }\end{array}$ \\
\hline ventilation & $L /$ min & $L /$ min & sec \\
Air & $6.7 \pm 1.0^{*}$ & $5.3 \pm 3.1$ & $23 \pm 5$ \\
$\mathrm{O}_{2}$ & $7.4 \pm 1.3 \dagger$ & $2.6 \pm 1.0 \dagger$ & $50 \pm 10 \dagger$ \\
\hline
\end{tabular}

* Standard deviation.

† Significantly different from corresponding value on air.

after tourniquet release and a marked prolongation of the interval between tourniquet release and the onset of hyperpnea. For all 35 subjects the control ventilation on air was $6.9 \pm 1.5 \mathrm{~L}$ per minute, hyperpnea appeared at $27 \pm 8$ seconds after tourniquet release, and the increment in ventilation was $5.3 \pm 2.5 \mathrm{~L}$ per minute. On oxygen the control ventilation was $7.8 \pm 2.2 \mathrm{~L}$ per minute, the interval was $49 \pm 11$ seconds, and the increment was $3.7 \pm 1.8 \mathrm{~L}$ per minute. Despite the reduction and delay of hyperpnea with oxygen, its onset was still abrupt.

Immediately after tourniquet release the mean arterial pressure fell slightly but regained the control level within 10 to 15 seconds. The pres-

TABLE II

Mean arterial blood changes in 7 subjects breathing air and oxygen after release of artery-occluding thigh tourniquets

\begin{tabular}{|c|c|c|c|c|}
\hline \multirow[b]{2}{*}{$\begin{array}{c}\text { Inspired } \\
\text { gas }\end{array}$} & \multirow{2}{*}{$\begin{array}{l}\text { Time after } \\
\text { tourniquet } \\
\text { release }\end{array}$} & \multicolumn{3}{|c|}{$\begin{array}{l}\text { Arterial blood values: control and change from } \\
\text { control after tourniquet release }\end{array}$} \\
\hline & & $\begin{array}{c}\text { Plasma } \mathrm{CO}_{2} \\
\text { content }\end{array}$ & $\mathrm{pH}$ & $\mathrm{PCO}_{2}$ \\
\hline $\begin{array}{l}\text { Air } \\
\mathrm{O}_{2}\end{array}$ & $\begin{array}{c}\text { sec } \\
\text { Control } \\
\text { Control }\end{array}$ & $\begin{array}{c}\text { vol \% } \\
56.6 \pm 2.9 \\
56.8 \pm 1.9\end{array}$ & $\begin{array}{l}7.37 \pm 0.02 \\
7.37 \pm 0.03\end{array}$ & $\begin{array}{c}m m \mathrm{Hg} \\
43.7 \pm 1.4 \\
42.9 \pm 3.3\end{array}$ \\
\hline $\begin{array}{l}\text { Air } \\
\mathrm{O}_{2}\end{array}$ & $\begin{array}{l}22 \pm 2 \\
23 \pm 4\end{array}$ & $\begin{array}{l}+1.2 \pm 1.4 \\
+0.1 \pm 0.5\end{array}$ & $\begin{aligned}-0.02 & \pm 0.01 \\
0.00 & \pm 0.01 *\end{aligned}$ & $\begin{array}{l}+3.0 \pm 2.3 \\
+0.4 \pm 0.8^{*}\end{array}$ \\
\hline $\begin{array}{l}\text { Air } \\
\mathrm{O}_{2}\end{array}$ & $\begin{array}{l}37 \pm 2 \\
37 \pm 4\end{array}$ & $\begin{array}{l}+2.2 \pm 1.7 \\
+1.5 \pm 0.7\end{array}$ & $\begin{array}{l}-0.05 \pm 0.02 \\
-0.04 \pm 0.02\end{array}$ & $\begin{array}{l}+7.1 \pm 3.7 \\
+5.6 \pm 3.0\end{array}$ \\
\hline $\begin{array}{l}\mathrm{Air} \\
\mathrm{O}_{2} \dagger\end{array}$ & $\begin{array}{l}53 \pm 6 \\
53 \pm 5\end{array}$ & $\begin{array}{l}+1.4 \pm 1.7 \\
+2.0+1.1\end{array}$ & $\begin{array}{l}-0.04 \pm 0.02 \\
-0.05 \pm 0.02\end{array}$ & $\begin{array}{l}+5.5 \pm 3.1 \\
+7.1 \pm 3.7\end{array}$ \\
\hline $\begin{array}{l}\text { Air } \\
\mathrm{O}_{2}\end{array}$ & $\begin{array}{l}79 \pm 10 \\
80 \pm 11\end{array}$ & $\begin{array}{l}+0.5 \pm 1.4 \\
+0.6 \pm 1.0\end{array}$ & $\begin{array}{l}-0.03 \pm 0.02 \\
-0.04 \pm 0.03\end{array}$ & $\begin{array}{l}+3.6 \pm 3.1 \\
+3.8 \pm 3.3\end{array}$ \\
\hline $\begin{array}{l}\mathrm{Air} \\
\mathrm{O}_{2}\end{array}$ & $\begin{array}{l}136 \pm 12 \\
140 \pm 6\end{array}$ & $\begin{array}{r}0.0 \pm 1.9 \\
-1.3 \pm 1.4\end{array}$ & $\begin{array}{l}-0.02 \pm 0.03 \\
-0.01 \pm 0.03\end{array}$ & $\begin{array}{l}+2.2 \pm 3.6 \\
+0.3 \pm 3.1\end{array}$ \\
\hline
\end{tabular}

* Significantly different from corresponding value on air $(p<0.05)$.

† Six subjects only. 


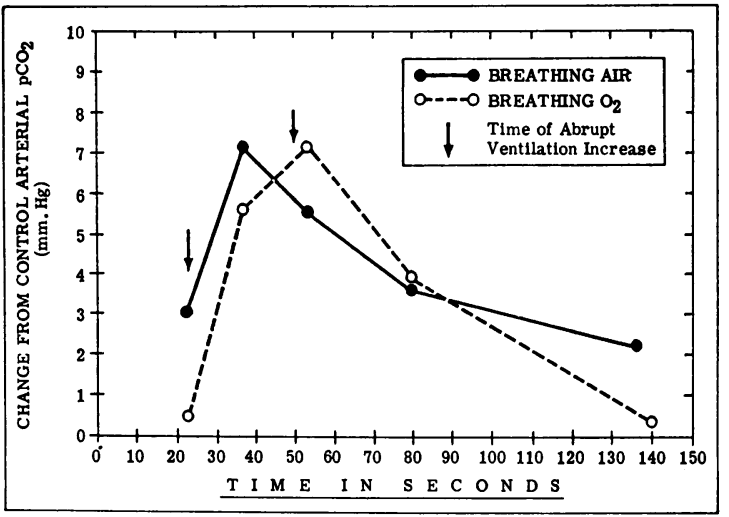

Fig. 2. Mean changes in arterial blood $\mathrm{P}_{\mathrm{CO}_{2}}$ After TOURNIQUET RELEASE IN 7 NORMAL SUBJECTS BREATHING AIR AND OXYGEN. Zero time represents the moment of release of thigh cuffs which had been inflated above arterial pressure for 15 minutes. The vertical arrows indicate the mean time at which hyperpnea appeared on air (left-hand arrow) and on oxygen. Other data on these subjects are presented in Tables I and II.

sure changes on air and oxygen breathing were similar. The time required for appearance of hyperpnea, as well as the lack of obvious neurogenic stimuli to account for its onset, indicates its mediation by a blood-borne stimulus arriving at the respiratory center or peripheral receptors.

The effects of breathing air and oxygen on tourniquet hyperpnea and on the time course of arterial blood gas changes were compared in seven subjects. The effect of tourniquet release on ventilation in these subjects is summarized in Table I. Table II presents the mean values for arterial $\mathrm{CO}_{2}$ content, $\mathrm{P}_{\mathrm{CO}_{2}}$, and $\mathrm{pH}$ in these seven subjects. About 10 seconds were required to collect a blood sample and the sampling time from which the means were calculated was the midpoint of the sampling period. From the table, and from Figure 2, which shows the change in arterial $\mathrm{P}_{\mathrm{CO}_{2}}$, it is apparent that the $\mathrm{CO}_{2}$ and $\mathrm{pH}$ changes were similar on air and oxygen, except that the changes with air came significantly earlier than those with oxygen. Inspection of Figure 2 indicates that the period of rapid increase in arterial $\mathrm{P}_{\mathrm{CO}_{2}}$ developed roughly 7 seconds sooner after tourniquet release when the subject was breathing air than when he was breathing oxygen. The slight delay in arterial blood change on oxygen is at least partially explained by the finding that the cardiac output is slightly lower and the mean circulation time longer after tourniquet release with oxygen breathing than with air breathing (18). However, the difference in timing of the apparent ventilation stimulus, so far as this is indicated by $\mathrm{P}_{\mathrm{CO}_{2}}$ change, accounts for only a small part of the delay in ventilation response while breathing oxygen; that is, for approximately 7 seconds of a 27 -second difference in response time. Furthermore, hyperpnea developed in the air-breathing group at a much lower $\mathrm{P}_{\mathrm{CO}_{2}}$ level than with oxygen breathing. Measurements were also made of arterial blood oxygen saturation: on air, the mean control value was 96.8 per cent, and the greatest change was $-2.2 \pm 2.1$ per cent at the 37-second sampling period; with oxygen breathing, saturation remained at 100 per cent. In six subjects a comparison was made of the timing of tourniquet hyperpnea while they breathed 15 per cent $\mathrm{O}_{2}, 85$ per cent $\mathrm{N}_{2}$, and of that while they breathed air. Arterial blood samples were taken at only two times, before tourniquet release and immediately after the onset of hyperpnea. In this series, the interval between tourniquet release and hyperpnea was $28 \pm 4$ seconds on air and $23 \pm 4$ seconds on 15 per cent oxygen; this time difference was significant $(p<0.01)$. On air, the change in arterial oxygen saturation after hyperpnea began was $-1.6 \pm 0.8$ per cent, and on 15 per cent oxygen it was $-3.3 \pm 1.0$ per cent, a significant difference $(p<0.05)$. The increase in arterial $\mathrm{P}_{\mathrm{CO}_{2}}$ on air was $4.7 \pm 2.9 \mathrm{~mm}$ $\mathrm{Hg}$, and on 15 per cent oxygen, $1.1 \pm 2.0 \mathrm{~mm} \mathrm{Hg}$, but the difference was not statistically significant.

Oxygen causes cerebral vasoconstriction, and if this effect were pronounced in the respiratory center it might account for the delay in tourniquet hyperpnea caused by oxygen. Accordingly, observations were made on the effect of other agents that alter cerebral blood flow.

Inhalation of $\mathrm{CO}_{2}$ (19-21) and intravenous infusion of 3.0 per cent $\mathrm{NaHCO}_{3}$ (20) both increase cerebral blood flow. Eight subjects were given infusions of $\mathrm{NaHCO}_{3}$, and three of these also breathed 3 per cent $\mathrm{CO}_{2}$ in air during study. The results in the two groups were similar. The combined data are presented in Table III. The effect of $\mathrm{CO}_{2}, \mathrm{NaHCO}_{3}$, or both was to reduce significantly the interval between tourniquet release and the onset of hyperpnea during oxygen breathing.

$\mathrm{NH}_{4} \mathrm{Cl}$ infusion decreases cerebral blood flow 
TABLE III

Effect of sodium bicarbonate infusion on the magnitude and timing of hyperpnea after tourniquet release

\begin{tabular}{|c|c|c|c|c|c|c|c|}
\hline & \multicolumn{3}{|c|}{ Control } & \multicolumn{3}{|c|}{ After tourniquet release } & \multirow{2}{*}{$\begin{array}{l}\text { Interval } \\
\text { between } \\
\text { tourniquet } \\
\text { release and } \\
\text { ventilation } \\
\text { increase } \\
\text { (in all } 8 \\
\text { subjects) }\end{array}$} \\
\hline & Ventilation & $\mathrm{pH}$ & $\mathrm{PCO}_{2}$ & $\begin{array}{l}\text { Increase in } \\
\text { ventilation }\end{array}$ & $\mathrm{pH}$ & $\mathrm{PcO} 2$ & \\
\hline & $L / \min$ & & $m m \mathrm{Hg}$ & $L / \min$ & & $m m H g$ & $\sec$ \\
\hline $\begin{array}{l}\text { (5 Subjects) } \\
\text { Air } \\
\text { Oxygen } \\
\text { Air-NaHCO } \mathrm{HCO}_{3} \\
\text { Oxygen-NaHCO} \\
\end{array}$ & $\begin{array}{l}5.8 \pm 1.1 \\
7.5 \pm 1.7 \\
6.9 \pm 1.7 \\
8.1 \pm 1.9\end{array}$ & $\begin{array}{l}7.40 \pm 0.02 \\
7.40 \pm 0.01 \\
7.46 \pm 0.03 \\
7.53 \pm 0.01\end{array}$ & $\begin{array}{l}40.7^{*} \\
41.7 \\
42.4 \\
43.1\end{array}$ & $\begin{array}{l}5.2 \pm 1.4 \\
3.2 \pm 1.6 \\
3.7 \pm 0.7 \\
3.3 \pm 1.3\end{array}$ & $\begin{array}{l}7.39 \pm 0.05 \\
7.38 \pm 0.03 \\
7.43 \pm 0.03 \\
7.46 \pm 0.04\end{array}$ & $\begin{array}{l}43.0 \\
47.8 \\
44.9 \\
47.5\end{array}$ & \\
\hline (In 3 other subjec & $3.0 \% \mathrm{CO}_{2}$ & $s$ added to th & nspired & & & & \\
\hline $\begin{array}{l}\text { Air } \\
\text { Oxygen } \\
\text { Air-NaHCO } \\
\text { Oxygen-NaHCO }\end{array}$ & $\begin{array}{r}6.5 \\
6.2 \\
12.0 \\
15.7\end{array}$ & $\begin{array}{l}7.36 \\
7.41 \\
7.45 \\
7.49\end{array}$ & $\begin{array}{l}43.0 \\
41.3 \\
44.6 \\
45.5\end{array}$ & $\begin{array}{l}3.6 \\
3.1 \\
2.8 \\
5.0\end{array}$ & $\begin{array}{l}7.34 \\
7.35 \\
7.41 \\
7.46\end{array}$ & & $\begin{array}{l}26 \pm 5 \\
49 \pm 9 \dagger \\
28 \pm 5 \\
37 \pm 8 \ddagger\end{array}$ \\
\hline
\end{tabular}

* $\mathrm{P}_{\mathrm{CO}_{2}}$ was determined in 4 subjects only.

† Significantly different from air ( $p<0.01$ ).

$\ddagger$ Significantly different from oxygen alone $(p<0.01)$.

(20). The results of $\mathrm{NH}_{4} \mathrm{Cl}$ infusion in three subjects are shown in Table IV. One subject had hyperventilation with $\mathrm{NH}_{4} \mathrm{Cl}$ infusion and resultant alkalosis. The other two subjects had decrease in $\mathrm{pH}$ with air breathing and $\mathrm{NH}_{4} \mathrm{Cl}$. The interval between tourniquet release and hyperpnea was prolonged during $\mathrm{NH}_{4} \mathrm{Cl}$ infusion in all three subjects, both on air and oxygen. In one subject, hyperpnea after tourniquet release did not occur at all with oxygen breathing during $\mathrm{NH}_{4} \mathrm{Cl}$ infusion. The ventilation increment after tourniquet release was de-

TABLE IV

Effect of $\mathrm{NH}_{4} \mathrm{Cl}$ infusion on the magnitude and timing of hyperpnea after tourniquet release in 3 subjects

\begin{tabular}{|c|c|c|c|c|c|c|}
\hline \multirow[b]{2}{*}{ Subj. } & \multirow[b]{2}{*}{ Condition } & \multicolumn{2}{|c|}{ Control } & \multicolumn{2}{|c|}{$\begin{array}{l}\text { After,tourniquet } \\
\text { release }\end{array}$} & \multirow{2}{*}{$\begin{array}{l}\text { Interval } \\
\text { between } \\
\text { tourniquet } \\
\text { release and } \\
\text { ventilation } \\
\text { increase }\end{array}$} \\
\hline & & Ventilation & $\mathrm{pH}$ & $\begin{array}{l}\text { Increase in } \\
\text { ventilation }\end{array}$ & $\mathrm{pH}$ & \\
\hline & & $L / \min$ & & $L / \min$ & & $\mathrm{sec}$ \\
\hline 1 & $\begin{array}{l}\text { Air } \\
\text { Oxygen } \\
\text { Air-NH}{ }_{4} \mathrm{Cl} \\
\text { Oxygen- } \mathrm{NH}_{4} \mathrm{Cl}\end{array}$ & $\begin{array}{l}6.4 \\
6.9 \\
7.5 \\
7.5\end{array}$ & $\begin{array}{l}7.37 \\
7.32 \\
7.34 \\
7.39\end{array}$ & $\begin{array}{l}3.9 \\
4.9 \\
2.4 \\
3.3\end{array}$ & $\begin{array}{l}7.35 \\
7.30 \\
7.32 \\
7.28\end{array}$ & $\begin{array}{r}29 \\
49 \\
48 \\
106\end{array}$ \\
\hline 2 & $\begin{array}{l}\text { Air } \\
\text { Oxygen } \\
\text { Air-NH}{ }_{4} \mathrm{Cl} \\
\text { Oxygen- } \mathrm{NH}_{4} \mathrm{Cl}\end{array}$ & $\begin{array}{l}10.3 \\
10.3 \\
32.6 \\
22.0\end{array}$ & $\begin{array}{l}7.45 \\
7.46 \\
7.53 \\
7.47\end{array}$ & $\begin{array}{r}14.7 \\
5.7 \\
9.4 \\
6.0\end{array}$ & $\begin{array}{l}7.39 \\
7.42 \\
7.51 \\
7.41\end{array}$ & $\begin{array}{l}54 \\
68 \\
70 \\
76\end{array}$ \\
\hline 3 & $\begin{array}{l}\text { Air } \\
\text { Oxygen } \\
\text { Air-NH} \\
\text { Oxygen- } \mathrm{Cl} \mathrm{H}_{4} \mathrm{Cl}\end{array}$ & $\begin{array}{r}8.6 \\
6.7 \\
9.5 \\
11.8\end{array}$ & $\begin{array}{l}7.43 \\
7.40 \\
7.39 \\
7.42\end{array}$ & $\begin{array}{c}3.8 \\
2.2 \\
2.9 \\
\text { NH* }^{*}\end{array}$ & $\begin{array}{l}7.40 \\
7.31 \\
7.33 \\
7.33\end{array}$ & $\begin{array}{c}27 \\
46 \\
75 \\
\text { NH* }^{*}\end{array}$ \\
\hline Mean & $\begin{array}{l}\text { Air } \\
\text { Oxygen } \\
\text { Air- } \mathrm{NH}_{4} \mathrm{Cl} \\
\text { Oxygen- } \mathrm{NH}_{4} \mathrm{Cl}\end{array}$ & $\begin{array}{r}8.4 \\
8.0 \\
16.5 \\
13.8\end{array}$ & $\begin{array}{l}7.42 \\
7.39 \\
7.42 \\
7.43\end{array}$ & $\begin{array}{l}7.5 \\
4.3 \\
4.9 \\
4.7 \dagger\end{array}$ & $\begin{array}{l}7.38 \\
7.34 \\
7.39 \\
7.34\end{array}$ & $\begin{array}{l}37 \\
54 \\
64 \\
91 \dagger\end{array}$ \\
\hline
\end{tabular}

* No hyperpneic response.

† Calculated from 2 subjects only since 1 subject had no hyperpneic response. 
TABLE V

Effect of aminophylline infusion on the magnitude and timing of hyperpnea after tourniquet release: mean values in 5 subjects

\begin{tabular}{|c|c|c|c|c|c|c|c|}
\hline & \multicolumn{3}{|c|}{ Control } & \multicolumn{3}{|c|}{ After tourniquet release } & \multirow{2}{*}{$\begin{array}{l}\text { Interval } \\
\text { between } \\
\text { tourniquet } \\
\text { release and } \\
\text { ventilation } \\
\text { increase }\end{array}$} \\
\hline & Ventilation & $\mathrm{pH}$ & $\mathrm{Pcos}$ & $\begin{array}{l}\text { Increase in } \\
\text { ventilation }\end{array}$ & $\mathrm{pH}$ & $\mathrm{PcO}_{2}$ & \\
\hline Air & $\begin{array}{c}L / \min \\
7.2 \pm 1.1\end{array}$ & $7.40 \pm 0.02$ & $\begin{array}{c}m m \mathrm{Hg} \\
38.2 \pm 2.2\end{array}$ & $\begin{array}{c}L / \min \\
6.3 \pm 2.6\end{array}$ & $7.38 \pm 0.03$ & $\begin{array}{c}m m H g \\
41.2 \pm 2.3\end{array}$ & $\begin{array}{c}\mathrm{sec} \\
33 \pm 11\end{array}$ \\
\hline Oxygen & $10.4 \pm 4.0$ & $7.45 \pm 0.01$ & $34.5 \pm 2.8$ & $4.9+2.8$ & $7.42 \pm 0.04$ & $37.8 \pm 4.4$ & $59 \pm 19$ \\
\hline $\begin{array}{l}\text { Air with } \\
\text { aminophylline } \\
\text { infusion }\end{array}$ & $11.4 \pm 7.4$ & $7.46 \pm 0.03$ & $32.3 \pm 3.8$ & $4.2 \pm 3.1$ & $7.42 \pm 0.04$ & $35.4 \pm 5.2$ & $>52^{*}$ \\
\hline $\begin{array}{l}\text { Oxygen with } \dagger \\
\text { aminophylline } \\
\text { infusion }\end{array}$ & $10.7 \pm 1.1$ & $7.45 \pm 0.05$ & $33.0 \pm 4.7$ & $4.2 \pm 1.1$ & $7.40 \pm 0.03$ & $36.7 \pm 4.8$ & $63 \pm 22$ \\
\hline
\end{tabular}

* Interval greater than on air alone in 4 subjects; 1 subject had no hyperpneic response.

$\dagger$ Four subjects only.

creased by $\mathrm{NH}_{4} \mathrm{Cl}$ in all three subjects during air breathing and in two of three subjects on oxygen.

The intravenous infusion of $500 \mathrm{mg}$ of aminophylline is reported to decrease cerebral blood flow by 25 to 35 per cent (22-24). As shown in Table V, five subjects had a significant prolongation of the interval between tourniquet release and hyperpnea when given aminophylline during air breathing. With oxygen breathing, the interval was not changed significantly. The magnitude of the ventilation increase was not changed significantly during either air or oxygen breathing by aminophylline.

In seven subjects, observations were made on the rates at which ventilation was increased by breathing 4.5 per cent $\mathrm{CO}_{2}$ in normal (21 per cent) and high (95 per cent) $\mathrm{O}_{2}$ mixtures. The results are summarized in Table VI. Since the ventilatory response to $\mathrm{CO}_{2}$ is slightly reduced at high oxygen tensions $(25,26)$, increases in ventilation over the control level are expressed as per cent of the ventilation increment that each subject attained on the appropriate gas mixture after 6 minutes. Ventilation increased much more slowly on 95 per cent $\mathrm{O}_{2}$ than on 21 per cent $\mathrm{O}_{2}$ during the first minute, after which the two ventilation-time curves were roughly parallel, with the high oxygen curve always lagging. Arterial $\mathrm{P}_{\mathrm{CO}_{2}}$ was substantially identical on the two mixtures. On 21 per cent $\mathrm{O}_{2}$ the values were: control, $42.7 \pm 3.4 \mathrm{~mm} \mathrm{Hg} ; 1$ minute (five subjects), $51.0 \pm 2.3 \mathrm{~mm} \mathrm{Hg}$; 6 minutes (five subjects), $51.5 \pm 2.9 \mathrm{~mm} \mathrm{Hg}$. On 95 per cent $\mathrm{O}_{2}$ the values were: control, $41.9 \pm 4.2 \mathrm{~mm} \mathrm{Hg} ; 1$ minute (five subjects), $52.4 \pm 6.6 \mathrm{~mm} \mathrm{Hg} ; 6$ minutes, $53.1 \pm 6.8 \mathrm{~mm} \mathrm{Hg}$. In two subjects samples were taken at 4 minutes and at 7 and 9 minutes on both normal and high oxygen tensions.

TABLE VI

Mean ventilation rate of 7 subjects at 1-minute intervals after beginning inhalation of $4.5 \% \mathrm{CO}_{2}$ at normal and high $\mathrm{O}_{2}$ tensions

\begin{tabular}{|c|c|c|c|c|c|c|c|c|}
\hline \multirow[b]{2}{*}{$\underset{\text { mixture }}{\mathrm{Gas}}$} & & \multicolumn{7}{|c|}{ Ventilation ( $L / \mathrm{min})$ and ventilation increase above control (as \% of 6-minute increase) } \\
\hline & & $\underset{\text { (air) }}{\text { Control }}$ & $1 \mathrm{~min}$ & $2 \mathrm{~min}$ & $3 \mathrm{~min}$ & $4 \mathrm{~min}$ & $5 \mathrm{~min}$ & $6 \mathrm{~min}$ \\
\hline \multirow{2}{*}{$\begin{array}{l}4.5 \% \mathrm{CO}_{2} \\
21 \% \mathrm{O}_{2} \\
74.5 \% \mathrm{~N}_{2}\end{array}$} & $(L / \min )$ & $8.0 \pm 1.6$ & $12.2 \pm 3.2$ & $15.7 \pm 4.4$ & $17.4 \pm 6.0$ & $18.1 \pm 3.9$ & $21.0 \pm 4.2$ & $20.7 \pm 4.9$ \\
\hline & $(\%)$ & 0 & $36 \pm 38$ & $61 \pm 43$ & $76 \pm 43$ & $80 \pm 16$ & $104 \pm 26$ & 100 \\
\hline \multirow{2}{*}{$\begin{array}{l}4.5 \% \mathrm{CO}_{2}, \\
95 \% \mathrm{O}_{2}\end{array}$} & $(L / \min )$ & $\begin{array}{c}\left(100 \% \mathrm{O}_{2}\right) \\
8.4 \pm 2.3\end{array}$ & $9.2 \pm 1.8^{*}$ & $12.5 \pm 3.4^{*}$ & $15.2 \pm 3.3^{*}$ & $15.8 \pm 3.6^{*}$ & $17.3 \pm 3.7^{*}$ & $18.3 \pm 2.9^{*}$ \\
\hline & $(\%)$ & 0 & $7 \pm 29^{*}$ & $36 \pm 41^{*}$ & $63 \pm 30$ & $71 \pm 28$ & $86 \pm 24^{*}$ & 100 \\
\hline
\end{tabular}

* Significantly less than the corresponding value on $4.5 \% \mathrm{CO}_{2}, 21 \% \mathrm{O}_{2}$. 
The $\mathrm{P}_{\mathrm{CO}_{2}}$ of these samples was similar to that of the 1- and 6-minute values in the other subjects. In each trial of $\mathrm{CO}_{2}$ breathing the $\mathrm{P}_{\mathrm{CO}_{2}}$ of the early and late arterial blood samples was remarkably constant. Of all 14 of these pairs, the greatest difference between early and late members of a pair was $3.0 \mathrm{~mm} \mathrm{Hg}$. In summary, breathing the two gas mixtures caused a prompt, substantially equal elevation in arterial $\mathrm{P}_{\mathrm{CO}_{2}}$, but ventilation increased much more slowly on 95 per cent $\mathrm{O}_{2}$ than on 21 per cent $\mathrm{O}_{2}$.

\section{DISCUSSION}

The identity of the primary stimulus responsible for tourniquet hyperpnea and the site of its action are not entirely clear. Mills (27) has reported that release of venous tourniquets will produce a very brief, mild hyperpnea in approximately 4 seconds, possibly related to an acute increase in pulmonary blood volume. The present tourniquet hyperpnea, produced by release of arterial tourniquets, is different in timing, quantity, and duration. The stimulus for this tourniquet hyperpnea, for reasons given earlier, appears to be blood-borne. The change in arterial blood oxygen after tourniquet release with the subject breathing air or 15 per cent oxygen seems too little to account for the hyperpnea. The increase in arterial $\mathrm{P}_{\mathrm{CO}_{2}}$ and the associated $\mathrm{pH}$ change could easily account for the increase in ventilation, given enough time to act. However, the prompt appearance of the hyperpnea and the abruptness with which it reaches full magnitude are not typical of the ventilatory response to inhaled $\mathrm{CO}_{2}$.

Grodins and co-workers ( 3 ) have shown that inhalation of 4.7 per cent $\mathrm{CO}_{2}$ in air by a normal subject will rapidly elevate the alveolar $\mathrm{P}_{\mathrm{CO}_{2}}$ to a near steady state level with little over- or undershooting. Calculations based on normal values for alveolar ventilation, lung volume, cardiac output, blood gases, and metabolic rate indicate that our subjects should have completed 90 per cent of the initial rapid change in alveolar $\mathrm{P}_{\mathrm{CO}_{2}}$ within 30 to 40 seconds after beginning inhalation of 4.5 per cent $\mathrm{CO}_{2}$. Arterial blood samples showed that a mean $\mathrm{P}_{\mathrm{CO}_{2}} 8 \mathrm{~mm} \mathrm{Hg}$ above the resting level had already been reached at 1 minute and was substantially unchanged thereafter. At 1 minute, however, the mean ventilation of the group breath- ing 4.5 per cent $\mathrm{CO}_{2}$ in air had increased by only about $4 \mathrm{~L}$ per minute. Ventilation thereafter continued to increase gradually, as previously described (1-3). By contrast, during air breathing, tourniquet hyperpnea, which almost immediately reached $5 \mathrm{~L}$ per minute, appeared at 23 seconds after cuff release, when the mean elevation of arterial $\mathrm{P}_{\mathrm{CO}_{2}}$ was only about $3 \mathrm{~mm} \mathrm{Hg}$. At this time the arterial $\mathrm{P}_{\mathrm{CO}_{2}}$ could hardly have been rising for more than 10 seconds. If the slow response to inhaled $\mathrm{CO}_{2}$ depends primarily on the time required for perfusing blood to raise the $\mathrm{CO}_{2}$ of the respiratory center, and if tourniquet hyperpnea also results from increased $\mathrm{CO}_{2}$ in the center, then it seems necessary to postulate that the tourniquet maneuver may in some way have the effect of greatly increasing blood flow through the center. This could perhaps account for the promptness with which tourniquet hyperpnea appears. Increased sensitivity to $\mathrm{CO}_{2}$ seems an unlikely explanation since tourniquet hyperpnea quickly levels off even though arterial $\mathrm{P}_{\mathrm{CO}_{2}}$ continues to rise for a few seconds more.

The effect of oxygen in delaying tourniquet hyperpnea and decreasing the response might result from a decrease in sensitivity to $\mathrm{P}_{\mathrm{CO}_{2}}$ change, a reduction in blood flow through the center, or both. It is well established that the ventilatory response to inhaled $\mathrm{CO}_{2}$ is diminished by high oxygen tensions. The effect of oxygen on the speed of response to inhaled $\mathrm{CO}_{2}$ has received little notice, except by White, Humm, Armstrong and Lundgren (25), who observed that ventilation increases more slowly when $\mathrm{CO}_{2}$ is given in oxygen than when it is given in air. Table VI shows that ventilation on 4.5 per cent $\mathrm{CO}_{2}$ increases much more slowly when the gas is given in 95 per cent $\mathrm{O}_{2}$ than when in 21 per cent $\mathrm{O}_{2}$. In particular, ventilation is much slower getting started on the high oxygen mixture, although the arterial $\mathrm{P}_{\mathrm{CO}_{2}}$ values at various times are nearly identical on the two mixtures. These findings are compatible with the hypothesis that oxygen delays and reduces tourniquet hyperpnea by reducing the perfusion rate of the center as well as by reducing sensitivity to $\mathrm{CO}_{2}$. However, to account for the delay, it is necessary to postulate that the vasoconstrictor effect of oxygen is much greater in the respiratory center than in the brain as whole. Kety and Schmidt (19) 
found a mean decrease of 13 per cent in the cerebral blood flow on 85 per cent oxygen, but calculations based on assumptions similar to those of Grodins and associates ( 3 ) suggest that blood flow through the center would have to be reduced by about 50 per cent to account for the effect of oxygen on the response rate to inhaled $\mathrm{CO}_{2}$ (see Appendix).

An attempt has also been made to calculate how much change in center flow would be needed to account for the effect of oxygen on tourniquet hyperpnea (see Appendix). Here, even more assumptions are needed because of the constantly changing arterial $\mathrm{P}_{\mathrm{CO}_{2}}$. The results indicate that a flow reduction to about one-fourth on oxygen might account for the effect. However, the absolute value of flow during tourniquet hyperpnea would need to be several times greater than that during $\mathrm{CO}_{2}$ inhalation. This conclusion is also grossly apparent from the comparative data already presented.

In summary, it appears that accounting for the differences in rate of response to tourniquet hyperpnea and to inhaled $\mathrm{CO}_{2}$ during air and oxygen breathing by postulating changes in perfusion rate of the respiratory center would require that perfusion of the center be markedly reduced by oxygen and markedly increased during the tourniquet procedure, possibly by substances released from hypoxic extremities. This would be facilitated by rich vascularization of this region. Histologic studies do, in fact, show great variation in the concentration of capillaries in different parts of the brain. The brain stem is among those regions which appear to be most richly supplied with capillaries $(28,29)$.

In order to explore further the possibility that changing perfusion rates of the respiratory center might influence the timing of tourniquet hyperpnea, observations were made on the effect of procedures known to alter over-all cerebral blood flow. Aminophylline and $\mathrm{NH}_{4} \mathrm{Cl}$, which decrease cerebral blood flow, each significantly delayed the appearance of hyperpnea on air, and $\mathrm{NH}_{4} \mathrm{Cl}$ probably augmented the delay produced by oxygen. $\mathrm{NaHCO}_{3}$ with $\mathrm{CO}_{2}$, which increases cerebral flow, significantly decreased the delay on oxygen, but did not affect the interval during air breathing. Multiple arterial $\mathrm{pH}$ determinations on several subjects did not show any effect of these proce- dures on the timing of arterial blood changes following tourniquet release. These observations are consistent with the hypothesis that the interval between tourniquet release and hyperpnea is related to the rate of cerebral blood flow, but are also open to other interpretations.

From the present data it is not possible to exclude participation of the peripheral chemoreceptors in the phenomena of tourniquet hyperpnea. The carotid body is stimulated by a rise in $\mathrm{P}_{\mathrm{CO}_{2}}$ and a fall in $\mathrm{pH}$, although the effect is much less than that produced by hypoxia $(2,30,31)$. It is richly perfused (5), and its perfusion rate appears to be altered markedly by change in oxygen tension of the blood (6). Evidence is not available, however, to indicate whether the various agents used here to change cerebral blood flow also affect carotid body perfusion in the same directions.

It is conceivable that chemical stimulation of the carotid body might account for the rapid occurrence of tourniquet hyperpnea during air breathing and that a high arterial oxygen tension might suppress the stimulus, as it can suppress the cyanide stimulus (7). The delayed response on oxygen would then represent the slower response of the respiratory center, now unmasked by removal of the carotid body stimulus. This postulate, however, would raise problems relating to the oxygenlike effects of aminophylline and ammonium chloride, and the opposing effect of bicarbonate.

The possibility also remains that some unidentified substance which is a respiratory stimulant may be released from the ischemic extremities and account for tourniquet hyperpnea. The release of such a substance from working muscles has been suggested to explain the hyperpnea of exercise $(32,33)$.

There is a striking parallelism between the course of blood changes and ventilation early in exercise and in tourniquet hyperpnea. With the onset of moderately severe exercise in unconditioned subjects there is an immediate increase in ventilation (34), presumably "neurogenic" in origin. This persists nearly unchanged in most subjects for 40 to 60 seconds, despite the development of a considerable increase in arterial $\mathrm{P}_{\mathbf{C O}_{2}}$ toward the end of this period. There is then an abrupt "secondary" increase in ventilation which appears to be a response to the change in arterial blood $(35,36)$. The abruptness of this response 
is reminiscent of tourniquet hyperpnea. In both exercise and tourniquet hyperpnea the arterial $\mathrm{P}_{\mathrm{CO}_{2}}$ is elevated for a few seconds before the response. In both cases large masses of hypoxic muscle are being perfused. Recently, Craig and Cummings (37) have shown that the "secondary" rise of ventilation during exercise develops much more gradually when subjects are breathing oxygen than when they are breathing air. These findings suggest that tourniquet hyperpnea and the "secondary" rise of ventilation early in exercise may be closely related phenomena.

Although the identity of the principal ventilatory stimulus in tourniquet hyperpnea and the site of its action are not yet clearly established, it is evident that the timing and magnitude can be greatly altered by procedures which also alter the rate of cerebral blood flow. The effect of changing perfusion rates in chemosensitive regions must be taken into account in the study of states characterized by a rapidly changing ventilation (38).

\section{SUMMARY AND CONCLUSIONS}

1. Observations have been made in normal subjects on the transient hyperpnea which follows release of tourniquets that have occluded arterial flow to the legs for 15 minutes. Hyperpnea appears abruptly a few seconds after the arterial blood begins to show an increase in $\mathrm{P}_{\mathrm{CO}_{2}}$, a fall in $\mathrm{pH}$, and a slight decrease in per cent oxygen saturation. The hyperpnea is believed to be caused by a blood-borne stimulus from the previously ischemic tissue, and the change in $\mathrm{P}_{\mathrm{CO}_{2}}$ appears large enough to be responsible.

2. The onset of tourniquet hyperpnea is considerably delayed when the subject breathes oxygen, or when he is pretreated with $\mathrm{NH}_{4} \mathrm{Cl}$ or aminophylline. The delay caused by oxygen is reduced by pretreatment with $\mathrm{NaHCO}_{3}$ and $\mathrm{CO}_{2}$ inhalation. The rate at which ventilation increases on inhalation of 4.5 per cent $\mathrm{CO}_{2}$ is significantly slower when the gas is mixed with 95 per cent oxygen than when it is mixed with 21 per cent oxygen.

3. It is concluded that the rate at which ventilation responds to an increase in arterial $\mathrm{P}_{\mathrm{CO}_{2}}$, and possibly to other blood-borne stimuli, can be slowed considerably by procedures which reduce cerebral blood flow and increased by procedures which increase cerebral flow. However, in order to account for the timing of tourniquet hyperpnea simply by change in the $\mathrm{CO}_{2}$ content of the respiratory center, it is necessary to postulate that the center is much more rapidly perfused during tourniquet hyperpnea than during $\mathrm{CO}_{2}$ inhalation, and that its perfusion rate is remarkably altered by oxygen and by some other substances which alter the over-all cerebral blood flow.

\section{APPENDIX}

If it be assumed that the ventilatory response to inhaled $\mathrm{CO}_{2}$ and to tourniquet release depends upon changes in the $\mathrm{P}_{\mathrm{CO}_{2}}$ of the respiratory center, the present data, together with certain further assumptions, permit making estimates of the perfusion rate of the center. Because the assumptions are necessarily inaccurate, the estimates are not advanced as having quantitative validity in absolute terms. Nevertheless, the calculations are useful because proportionate changes in estimated perfusion rates under different circumstances are so great as to indicate either a quite unexpected capacity for altering flow in the center, or a failure to take into account some other, apparently unfamiliar, regulatory mechanism.

The basic assumptions are as follows: 1) that increase in ventilation rate is proportional to increase in $\mathrm{P}_{\mathrm{CO}_{2}}$ within the respiratory center; 2) that the respiratory center is a uniformly perfused volume of tissue with a uniform $\mathrm{P}_{\mathrm{CO}_{2}}$, equal to that of its venous blood; 3 ) that the perfusion rate of the respiratory center does not change during the course of a particular inhalation experiment or of a particular episode of tourniquet hyperpnea; 4) that the $\mathrm{CO}_{2}$ dissociation curves of arterial and venous blood and of respiratory center tissue are linear and identical; and 5) that the contribution to respiratory center $\mathrm{P}_{\mathrm{CO}_{2}}$ made by the metabolism of the center itself can be neglected.

Assumption 1 implies that no other regulatory mechanism is operative; as noted above, this may be incorrect. Assumption 3 is almost certainly incorrect. As pointed out by DeFares, Derksen and Duyff (38), the vessels of the center, like other cerebral vessels, are probably dilated by an increase in $\mathrm{CO}_{2}$. Assumption 4 is at best an approximation. The deviation from linearity of the blood dissociation curves over a small $\mathrm{P}_{\mathrm{CO}_{2}}$ range is not large, but the curves are not identical. Adequate information is not available for the tissue dissociation curve.

Let $B=$ the increase in arterial $\mathrm{P}_{\mathrm{CO}_{2}}$ above the resting level $(\mathrm{mm} \mathrm{Hg}) ; C=$ the increase in $\mathrm{P}_{\mathrm{CO}_{2}}$ of the respiratory center and its venous blood above the resting level $(\mathrm{mm} \mathrm{Hg}) ; V=$ volume of the respiratory center $(\mathrm{ml})$; $F=$ blood flow through the respiratory center $(\mathrm{ml} / \mathrm{sec})$; $t=$ time in seconds, measured from the beginning of a change in arterial $\mathrm{P}_{\mathrm{CO}_{2}}$; and $k=F / V$ in seconds ${ }^{-1}$, the turnover rate of the respiratory center.

The data obtained from the experiments on inhalation 
of 4.5 per cent $\mathrm{CO}_{2}$ can be used to estimate the effect of oxygen breathing on respiratory center perfusion under these circumstances, granting the preceding assumptions. It has been shown (3) that inhalation of 4.5 per cent $\mathrm{CO}_{2}$ by a normal subject causes an abrupt rise of arterial $\mathrm{P}_{\mathrm{CO}_{2}}$ to a plateau 8 to $10 \mathrm{~mm} \mathrm{Hg}$ above the resting level, and the present experiments show that such a plateau had already been established after 1 minute. Estimates

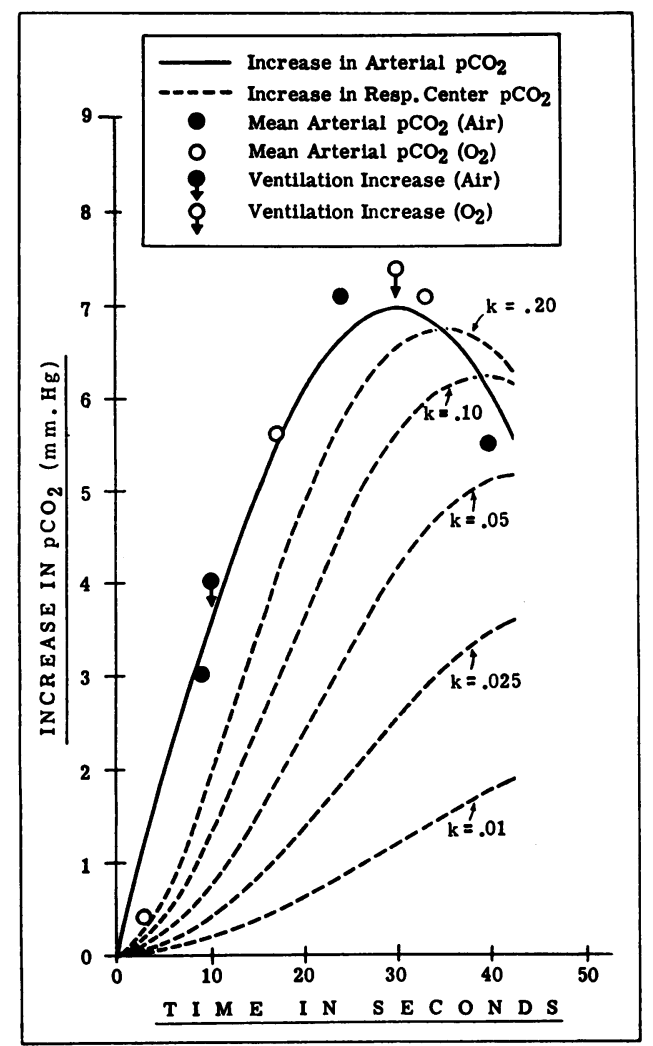

Fig. 3. Calculated changes in $\mathrm{P}_{\mathrm{CO}_{2}}$ of the ReSPIRATORY CENTER CORRESPONDING TO THE INDICATED Change in arterial $\mathbf{P}_{\mathrm{CO}_{2}}$ AND to Different Rates of BLOOD FLOW THROUGH THE CENTER. The solid line $\left[\mathrm{P}_{\mathrm{CO}_{2}}\right.$ $=7 \sin (\pi / 60) t]$ is based on experimental data and is intended to approximate the time course of change in arterial $\mathrm{P}_{\mathrm{CO}_{2}}$ following tourniquet release. Time is taken as beginning with the onset of change in arterial $\mathrm{P}_{\mathrm{Co}_{2}}$. The mean arterial $\mathrm{P}_{\mathrm{CO}_{2}}$ values actually obtained after tourniquet release during air breathing (solid circles) and oxygen breathing (open circles) are plotted, allowing 13 seconds for arterial changes to appear during air breathing and 20 seconds during oxygen breathing (see text). The mean times at which hyperpnea occurred on air and oxygen are indicated. The dotted lines show the calculated time course of change in $\mathrm{P}_{\mathrm{CO}_{2}}$ of the respiratory center, given the same arterial curve in each case but different perfusion rates of the center. The perfusion rates are designated as $k$ (the ratio of blood flow to tissue volume in seconds ${ }^{-1}$ ). based on normal values for instrumental dead space, alveolar ventilation, lung volume, cardiac output, blood gases, and metabolic rate indicate that our subjects should have completed 90 per cent of the initial rapid change in alveolar $\mathrm{PCO}_{2}$ in 30 to 40 seconds after being switched to the $\mathrm{CO}_{2}$ mixture, and the arterial plateau should have been substantially established by $40 \mathrm{sec}-$ onds. In view of the rapidity with which the new arterial $\mathrm{P}_{\mathrm{CO}_{2}}$ level is established relative to the slow subsequent change in ventilation, it seems allowable to consider the new level as appearing in a simple, step-like fashion at 40 seconds. $B$, the increase in arterial $\mathrm{P}_{\mathrm{CO}_{2}}$ above the resting level, is therefore given a constant value of $8 \mathrm{~mm}$ $\mathrm{Hg}$ and time, $t$, is taken to begin at 40 seconds after switching to $\mathrm{CO}_{2}$. From the assumptions of linearity and identity in the $\mathrm{CO}_{2}$ dissociation curves, the statement that the center gains the $\mathrm{CO}_{2}$ given up by the blood can be written as

$$
V d C=F(B-C) d t
$$

Allowing that $C=0$ when $t=0$, this yields

$$
C=B\left(1-e^{-k t}\right)
$$

In order to obtain a value for the turnover rate, $k$, a value for $C$ at a time, $t$, must be obtained, using assumption 1. If an increase of $2.5 \mathrm{~L}$ per minute in ventilation is allowed as the full response, in the absence of hypoxia, to an increase of $1 \mathrm{~mm} \mathrm{Hg}$ in arterial $\mathrm{P}_{\mathrm{CO}_{2}}(3,26)$ and hence, presumably, in respiratory center $\mathrm{P}_{\mathrm{CO}_{2}}$, then the data of Table VI can be used for estimating relative respiratory center flow rates. The 2 -minute values are chosen because the ventilation increments are roughly similar to those of the tourniquet experiments, with which they will be compared below. $C$ is obtained by dividing each ventilation increment by $2.5, B$ is taken as 8 , and $t$ as 80 seconds $(120-40)$. Substituting these values in Equation 2 yields a $k$ of 0.006 on air and of 0.003 on oxygen. These are not advanced as estimates of actual flow rate, but as suggestive of a large effect of oxygen in reducing the rate of flow through the respiratory center.

In the case of tourniquet hyperpnea, $B$, the arterial $\mathrm{P}_{\mathrm{CO}_{2}}$, is changing rapidly during the ventilatory response and it is desirable to choose a simple function of time which describes $B$ in approximate terms. For this purpose let $B=7 \sin (\pi / 60) t$. This curve is plotted in Figure 3. The actual first 3 mean values for increase in arterial $\mathrm{P}_{\mathrm{CO}_{2}}$ after tourniquet release on air and on oxygen, shown in Figure 2, are also plotted in Figure 3 to demonstrate their agreement with the hypothetical arterial curve, at least up to 40 seconds from the beginning of increase in $\mathrm{P}_{\mathrm{CO}_{2}}$. Time in Figure 3 begins with the increase in arterial $\mathrm{P}_{\mathrm{CO}_{2}}$, which is estimated from the data of Figure 2 to begin at 13 seconds after tourniquet release on air and 20 seconds after release on oxygen. Accordingly, these intervals are subtracted from the times given in Table II and Figure 2 to yield the times shown in Figure 3. The agreement is considered satisfactory as an approximate description of $B$. 
Substituting this value of $B$ in Equation 1 gives

$$
d C+k C d t=7 k \sin (\pi / 60) t d t
$$

This yields

$$
C=\frac{7 k[k \sin (\pi / 60) t-\pi / 60 \cos (\pi / 60) t]+K e^{-k t}}{k^{2}+(\pi / 60)^{2}}
$$

$K$, the integration constant, is evaluated by setting $C=0$ when $t=0$, yielding

$$
C=\frac{7 k\left[k \sin (\pi / 60) t-\pi / 60 \cos (\pi / 60) t+\pi / 60 e^{-k t}\right]}{k^{2}+(\pi / 60)^{2}}
$$

In Figure 3 this function is plotted to show how $C$ would vary with $t$, given the same arterial $\mathrm{P}_{\mathrm{CO}_{2}}$ curve but different perfusion rates of the center, represented by different values of $k$.

Figure 3 illustrates some relationships which follow from acceptance of the hypotheses that variations in perfusion rate principally account for variations in response time and that the simple model just described usefully simulates reality.

If tourniquet hyperpnea is assumed to result simply from increase in $\mathrm{P}_{\mathrm{CO}_{2}}$ of the respiratory center, then a rapid perfusion rate must be postulated. Since tourniquet hyperpnea on air begins abruptly at a rate not much under $5 \mathrm{~L}$ per minute and shortly exceeds that, it is a conservative choice to assign $2 \mathrm{~mm} \mathrm{Hg}$ as the increase in center $\mathrm{P}_{\mathrm{CO}_{2}}$ at the onset of hyperpnea. Table VII presents the $k$ values corresponding to increments of 1,2 , and $3 \mathrm{~mm} \mathrm{Hg} \mathrm{P}_{\mathrm{CO}_{2}}$ in the respiratory center at various intervals after the onset of arterial blood changes. When the interval is taken to be 10 seconds, as in the seven subjects of Tables I and II, $a k$ of 0.20 is required for a $\mathrm{P}_{\mathrm{CO}_{2}}$ of $2 \mathrm{~mm} \mathrm{Hg}$. Allowing an interval of 15 seconds, to correspond with the slightly longer response time of most subjects, still yields a $k$ of 0.08 .

To account for the change in response time on oxygen within the limitations of the present assumptions, a marked reduction in perfusion rate must be postulated. If a $2 \mathrm{~mm} \mathrm{Hg}$ increase in $\mathrm{P}_{\mathrm{CO}_{2}}$ again is taken as the response "threshold," the $k$ value appropriate to the 30 second response time on oxygen is 0.02 (Table VII). This perfusion rate is only one-fourth as large as that occurring on air by the more conservative estimate. It may also be noted that a reduction in $k$ of this degree has the effect of reducing considerably the maximal increase which occurs in $\mathrm{P}_{\mathrm{CO}_{2}}$ of the center and delaying the time at which this maximum comes.

It is reiterated that these "perfusion rates" cannot be advanced as representing the actual perfusion rate of the "respiratory center." The calculations emphasize, however, that acceptance of the postulate that changes in $\mathrm{P}_{\mathrm{CO}_{2}}$ of the center can account for both tourniquet and $\mathrm{CO}_{2}$ inhalation hyperpnea, and acceptance of the simple model presented here, impose an apparent need to accept also that oxygen inhalation reduces center flow proportionately much more than over-all cerebral flow,

\begin{tabular}{|c|c|c|c|}
\hline \multirow{2}{*}{$\begin{array}{c}\text { Increase in } \\
\text { Pcos of } \\
\text { respiratory } \\
\text { center }(\mathrm{mm} \mathrm{Hg})\end{array}$} & \multicolumn{3}{|c|}{$\begin{array}{l}\text { Perfusion rate of respiratory center } \\
\qquad k\left(\mathrm{sec}^{-1}\right)\end{array}$} \\
\hline & $t=10 \mathrm{sec}$ & $t=15 \mathrm{sec}$ & $t=30 \mathrm{sec}$ \\
\hline $\begin{array}{l}1 \\
2 \\
3\end{array}$ & $\begin{array}{l}0.07 \\
0.20 \\
0.66\end{array}$ & $\begin{array}{l}0.03 \\
0.08 \\
0.14\end{array}$ & $\begin{array}{l}0.01 \\
0.02 \\
0.03\end{array}$ \\
\hline
\end{tabular}
and that center flow is considerably greater during
TABLE VII

* The increment in arterial $\mathrm{P}_{\mathrm{CO}_{2}}$ is taken to have the numerical value: $\Delta \mathrm{P}_{\mathrm{CO}_{2}}=7$ sin $(\pi / 60) t$ during the time interval, 0 to $40 \mathrm{sec}$.

tourniquet hyperpnea than during $\mathrm{CO}_{2}$ inhalation. The need for further investigation of the subject is apparent.

\section{REFERENCES}

1. Padget, $P$. The respiratory response to carbon dioxide. Amer. J. Physiol. 1928, 83, 384.

2. Hesser, C. M. Central and chemoreflex components in the respiratory activity during acid-base displacements in the blood. Acta physiol. scand. 1949, 18, suppl. 64.

3. Grodins, F. S., Gray, J. S., Schroeder, K. R., Norins, A. L., and Jones, R. W. Respiratory responses to $\mathrm{CO}_{2}$ inhalation. A theoretical study of a nonlinear biological regulator. J. appl. Physiol. 1954, 7, 283.

4. Watt, J. G., Dumke, P. R., and Comroe, J. H., Jr. Effects of inhalation of 100 per cent and 14 per cent oxygen upon respiration of unanesthetized dogs before and after chemoreceptor denervation. Amer. J. Physiol. 1943, 138, 610.

5. Daly, M. DeB., Lambertsen, C. J., and Schweitzer, A. Observations on the volume of blood flow and oxygen utilization of the carotid body in the cat. J. Physiol. (Lond.) 1954, 125, 67.

6. De Castro, F. Sur la structure de la synapse dans les chemocepteurs: Leur mécanisme d'excitation et rôle dans la circulation sanguine locale. Acta physiol. scand. 1951, 22, 14.

7. Heymans, C. Action of drugs on carotid body and sinus. Pharmacol. Rev. 1955, 7, 119.

8. Stead, E. A., Jr., and Warren, J. V. Cardiac output in man: An analysis of the mechanisms varying the cardiac output based on recent clinical studies. A.M.A. Arch. intern. Med. 1947, 80, 237.

9. Hickam, J. B. Hyperpnea following release of arterial tourniquets. Fed. Proc. 1952, 11, 69.

10. Dejours, P., Mithoefer, J. C., and Teillac, A. Essai de mise en évidence de chémorécepteurs veineux de ventilation. J. Physiol. (Paris) 1955, 47, 160.

11. Ross, J. C., Hickam, J. B., and Frayser, R. The effect of changing cerebral blood flow on the response time of the respiratory center (abstract). J. clin. Invest. 1959, 38, 1036. 
12. Drabkin, D. L., and Austin, J. H. Spectrophotometric studies. II. Preparation from washed blood cells; nitric oxide hemoglobin and sulfhemoglobin. J. biol. Chem. 1935, 112, 51.

13. Hickam, J. B., and Frayser, R. Spectrophotometric determination of blood oxygen. J. biol. Chem. 1949, 180, 457.

14. Rosenthal, T. B. The effect of temperature on the $\mathrm{pH}$ of blood and plasma in vitro. J. biol. Chem. 1948, 173, 25.

15. Van Slyke, D. D., and Neill, J. M. The determination of gases in blood and other solutions by vacuum extraction and manometric measurements. I. J. biol. Chem. 1924, 61, 523.

16. Van Slyke, D. D., and Sendroy, J., Jr. Studies of gas and electrolyte equilibria in blood. XV. Line charts for graphic calculations by the Henderson-Hasselbalch equation, and for calculating plasma carbon dioxide content from whole blood content. J. biol. Chem. 1928, 79, 781.

17. Dill, D. B., Daly, C., and Forbes, W. H. The $\mathrm{pK}^{\prime}$ of serum and red cells. J. biol. Chem. 1937, 117, 569.

18. Daly, W., and Bondurant, S. Hemodynamic effects of oxygen breathing (abstract). J. clin. Invest. 1961, 40, 1031.

19. Kety, S. S., and Schmidt, C. F. The effects of altered arterial tension of carbon dioxide and oxygen on cerebral blood flow and cerebral oxygen consumption of normal young men. J. clin. Invest. 1948, 27, 484.

20. Schieve, J. F., and Wilson, W. P. The changes in cerebral vascular resistance of man in experimental alkalosis and acidosis. J. clin. Invest. 1953, 32, 33.

21. Novack, P., Shenkin, H. A., Bortin, L., Goluboff, B., and Soffe, A. M. The effects of carbon dioxide inhalation upon the cerebral blood flow and cerebral oxygen consumption in vascular disease. J. clin. Invest. 1953, 32, 696.

22. Wechsler, R. L., Kleiss, L. M., and Kety, S. S. The effects of intravenously administered aminophylline on cerebral circulation and metabolism in man. J. clin. Invest. 1950, 29, 28.

23. Moyer, J. H., Tashnek, A. B., Miller, S. I., Snyder, H., and Bowman, R. O. The effect of theophylline with ethylenediamine (aminophylline) and caffeine on cerebral hemodynamics and cerebrospinal fluid pressure in patients with hypertensive headaches. Amer. J. med. Sci. 1952, 224, 377.

24. Moyer, J. H., Miller, S. I., Tashnek, A. B., and Bowman, R. The effect of theophylline with ethylenediamine (aminophylline) on cerebral hemodynamics in the presence of cardiac failure with and without Cheyne-Stokes breathing. J. clin. Invest. 1952, 31, 267.

25. White, C. S., Humm, J. H., Armstrong, E. D., and Lundgren, N. P. V. Human tolerance to acute exposure to carbon dioxide. Report no. 1: Six per cent carbon dioxide in air and in oxygen. J. Aviat. Med. 1952, 23, 439.

26. Lloyd, B. B., Jukes, M. G. M., and Cunningham, D. J. C. The relation between alveolar oxygen pressure and the respiratory response to carbon dioxide in man. Quart. J. exp. Physiol. 1958, 43, 214.

27. Mills, J. N. Hyperpnoea in man produced by sudden release of occluded blood. J. Physiol. (Lond.) 1944, 103, 244.

28. Lockard, I., Barham, J. R., Jr., Forlidas, N. G., Jr., and Myers, R. B. Simultaneous histologic demonstration of blood vessels, nerve cells and nerve fibers within the central nervous system. J. comp. Neurol. 1959, 112, 169.

29. Lockard, I. Capillary patterns in the central nervous system and their possible relation to disease (abstract). Anat. Rec. 1960, 136, 236.

30. Heymans, C. Chemoreceptors and regulation of respiration. Acta physiol. scand. 1951, 22, 4.

31. Bartels, H., and Witzleb, E. Der Einfluss des arteriellen $\mathrm{CO}_{2}$-Druckes auf die chemoreceptorischen Aktionspotentiale im Carotissinusnerven. Pflüg. Arch. ges. Physiol. 1956, 262, 466.

32. Asmussen, E., and Nielsen, M. Studies on the regulation of respiration in heavy work. Acta physiol. scand. 1946, 12, 171.

33. Asmussen, E., and Nielsen, M. Pulmonary ventilation and effect of oxygen breathing in heavy exercise. Acta physiol. scand. 1958, 43, 365.

34. Krogh, A., and Lindhard, J. The regulation of respiration and circulation during the initial stages of muscular work. J. Physiol. (Lond.) 1913, 47, 112.

35. Hickam, J. B., Pryor, W. W., Page, E. B., and Atwell, R. J. Respiratory regulation during exercise in unconditioned subjects. J. clin. Invest. 1951, 30, 503 .

36. Bannister, R. G., Cunningham, D. J. C., and Douglas, C. G. The carbon dioxide stimulus to breathing in severe exercise. J. Physiol. (Lond.) 1954, 125, 90.

37. Craig, F. N., and Cummings, E. G. Breathing in brief exercise. J. appl. Physiol. 1960, 15, 583.

38. DeFares, J. G., Derksen, H. E., and Duyff, J. W. Cerebral blood flow in the regulation of respiration. (Studies in the regulation of respiration, 1.) Açta physiol. pharmacol. neerl. 1960, 9, 327. 